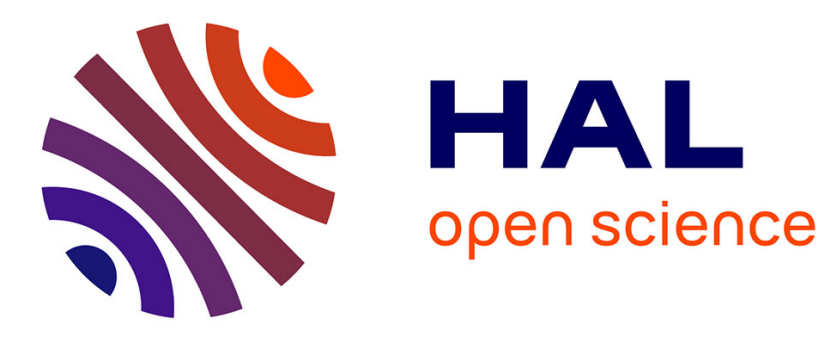

\title{
A new insight on induced-tribological behaviour of hypereutectic Al-Si alloys manufactured by selective laser melting
}

\author{
Nan Kang, Mohamed El Mansori
}

\section{- To cite this version:}

Nan Kang, Mohamed El Mansori. A new insight on induced-tribological behaviour of hypereutectic Al-Si alloys manufactured by selective laser melting. Tribology International, 2019, pp.1-6. 10.1016/j.triboint.2019.04.035 . hal-02641250

\author{
HAL Id: hal-02641250 \\ https://hal.science/hal-02641250
}

Submitted on 28 May 2020

HAL is a multi-disciplinary open access archive for the deposit and dissemination of scientific research documents, whether they are published or not. The documents may come from teaching and research institutions in France or abroad, or from public or private research centers.
L'archive ouverte pluridisciplinaire HAL, est destinée au dépôt et à la diffusion de documents scientifiques de niveau recherche, publiés ou non, émanant des établissements d'enseignement et de recherche français ou étrangers, des laboratoires publics ou privés. 


\title{
A new insight on induced-tribological behaviour of hypereutectic Al-Si alloys manufactured by selective laser melting
}

\author{
Nan Kang ${ }^{\mathrm{a}, *}$, Mohammed EL Mansori ${ }^{\mathrm{b}, \mathrm{c}}$ \\ ${ }^{a}$ Key Laboratory of Metal High Performance Additive Manufacturing and Innovative Design, MIIT China, Northwestern Polytechnical University, PR China \\ ${ }^{\mathrm{b}}$ MSMP Laboratory, EA-7350, Arts et Metiers ParisTech, Aix en Provence, France \\ ${ }^{\mathrm{c}}$ Texas A\&M Engineering Experiment Station, College Station, TX, 77843, USA
}

A B S T R A C T

Keywords:

Hypereutectic Al-Si alloys

Selective laser melting

Tribology behaviour

Microstructure
In this work, the tribological behaviour of selective laser melting (SLM) processed hypereutectic Al-Si alloy is investigated by the ball on disc test with focus on the effect of silicon content (18 and 50 wt \%). Different from the conventional casted sample, the SLM processed sample shows an ultra-fine microstructure with silicon size inferior to $5 \mu \mathrm{m}$. Indeed, the SLM processed hypereutectic Al-Si alloy illustrates a pseudo-eutectic microstructure consisted by supersaturated $\mathrm{Al}(\mathrm{Si})$ and primary silicon. Both the SLM processed $\mathrm{Al}-18 \mathrm{Si}$ and $\mathrm{Al}-50 \mathrm{Si}$ presents low wear rate about of 7.0 and $8.1 \diamond 10^{-4} \mathrm{~mm}^{3} /(\mathrm{N} \vee \mathrm{m})$ respectively. Moreover, the wear mechanisms of conventional casted and SLM processed hypereutectic Al-Si alloys are compared and discussed.

\section{Introduction}

Al-Si alloys are well known to their low density, high strength, high castbility and low cost [1]. According to the silicon content, the Al-Si alloys can be simply divided into three different types: (1) hypoeutectic ( $<10 \mathrm{wt} \% \mathrm{Si})$, (2) eutectic (10-13 wt\% Si) and (3) hypereutectic ( $>13 \mathrm{wt} \% \mathrm{Si}$ ). Hypereutectic Al-Si alloys are well known for their high wear and corrosion resistance with application in automobile and aerospace industries [2]. As reported by Deuis et al. [3], the size and distribution of primary silicon have a significant influence on mechanical and chemical properties. In general, the microstructure with fine and uniformed primary silicon shows high strength, wear/corrosion resistance [4]. Therefore, several processes have been considered to produce the component with ultra-fine microstructure. For instance, Hanna et al. [5] and Li et al. [6] indicated that adding a modification agent, such as Ce, Sr and P, would be an effective way to improve the mechanical properties by refining the primary silicon phase. Moreover, the modified Al-Si alloys cannot be refactorized for the second time, which causes significant wasting of resources. Another way to refine the microstructure of hypereutectic Al-Si alloys is rapid solidification $[7,8]$, which exhibits a reduction of cost and no limits of composition.

Selective laser melting (SLM) is one important kind of powder bed additive manufacturing, which shows great potential application in producing of complex component [9]. In this process, the high-energy laser beam is focused into several micrometre for obtaining the high energy density and processing accuracy [10]. Thus, both the heating and cooling rates are much higher than that of traditional manufacturing process. According to the reported of $\mathrm{Gu}$ et al. [11], the cooling rate of SLM ranged between $10^{3}-10^{7} \mathrm{~K} / \mathrm{s}$, which may create some mestable [12] or amorphous [13] structure in as-fabricated sample. In our previous work, Al-18Si [14] and Al-50Si [2] are successfully manufactured by SLM process from powder mixture. Due to the ultra-high cooling rate, the microstructure of SLM processed Al-Si sample is much finer than that of the conventional casted sample. Thus, the previous theory about friction and wear properties of casted hypereutectic Al-Si alloys is not suitable to SLM processed case anymore. Similar results were also being observed in the case of Ti-based alloys $[15,16]$. Unfortunately, as one important high-wear resistance alloys, no work has been preformed in case of hypereutectic Al-Si alloys.

In this work, the hypereutectic Al-Si alloys with several silicon contents were successfully manufactured by SLM processed with high relative density. Then, the friction and wear behaviour of the SLM processed samples were determined and investigated with focus on relationship with microstructure. Last but not least, a comparative study was carried out between SLM processed samples and conventional casted sample.

\section{Experimental details}

The spherical $\mathrm{Al}$ and $\mathrm{Al}-12 \mathrm{Si}$, which is prepared by gas atomization,

\footnotetext{
${ }^{*}$ Corresponding author. State Key Laboratory of Solidification Processing, Northwestern Polytechnical University, Xi'an Shaanxi 710072, PR China. E-mail address: nan.kang@nwpu.edu.cn (N. Kang).
} 

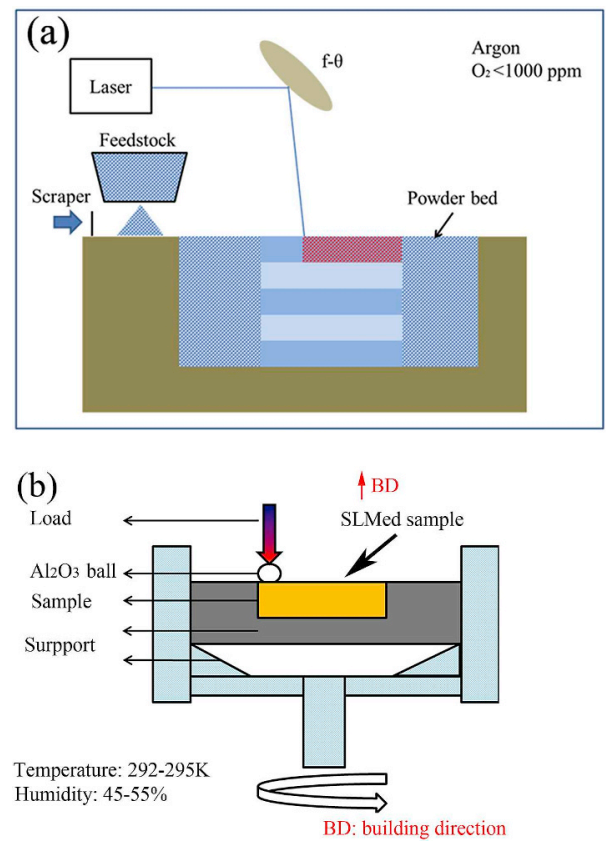

Fig. 1. Schematic illustration of (a) SLM system and (b) ball-on-disc wear test instrument.

and irregular Si powders, were used in this investigation. The details about feedstock materials can be seen in our previous work in Refs. $[2,14]$. The designed chemical compositions of hypereutectic Al-Si alloys are $18 \mathrm{wt} \%$ and $50 \mathrm{wt} \%$. The cubic samples with dimension of $8 \diamond 8 \diamond 8 \mathrm{~mm}^{3}$ are prepared on pure Al substrate plates, which is sandblasted before and heated up to $80^{\circ} \mathrm{C}$ during SLM process. A commercial available SLM system ((MCP-realizer SLM 250, MCP-HEK Tooling $\mathrm{GmbH}$, Germany)) was employed in this study. An x-y-z galvo scanner was used to scan the laser beam with spot size of $40 \mu \mathrm{m}$ (Ytterbium single-mode, continuous wave fibre laser). The maximum laser power and scanning speed of this system are $400 \mathrm{~W}$ and $5 \mathrm{~m} / \mathrm{s}$, respectively. All the samples are fabricated in pure argon environment with very low oxygen content $\left(\mathrm{O}_{2}<0.2 \%\right)$ for avoiding oxidation. This system is schematically illustrated in Fig. 1 (a).

The microstructure was observed by using optic microscopy (OM) and scanning electron microscopy (SEM) and then analysis by using image analysis process. The ball-on-disc wear test (CSM-TRIBOMETER instruments, Switzerland), which is shown in Fig. 1 (b), was employed to determine the tribological behaviour under ambient atmosphere (temperature: $19-22^{\circ} \mathrm{C}$, humidity: $45-55 \%$ ), such as friction coefficient, wear rate etc. All sliding tests were performed on the cross section from top view side, which is grinded with $120 \#$, 400\#, 800\#, 1500\#, $2000 \#$ and $4000 \#$ grid emery paper, and finally polished using $0.02 \mu \mathrm{m}$ $\mathrm{SiO}_{2}$ polishing solution. The counterpart was a $6 \mathrm{~mm}$ diameter $\mathrm{Al}_{2} \mathrm{O}_{3}$ ball with a mirror-finished surface (unused condition) $[17,18]$. Wear rate was defined as the worn volume per unit of normal load and sliding distance. After the sliding procedure, the cross-sectional area of the worn tracks was measured through an Altisurf 500 profilometer. The average value corresponded to a set of 6 random positions along the worn track for each specimen. This quantity has a special physical significance. It is inversely proportional to the energy per unit volume of material removal or specific dissipated energy in sliding distance.

\section{Results}

Fig. 2 presents the parameter optimizations of laser power on relative density of Al-18Si (see in Fig. 2 (a)) and Al-50Si (see in Fig. 2 (a)), which were measured by image analysis from 20 pictures for each sample. For both alloys, it can be observed that the relative density
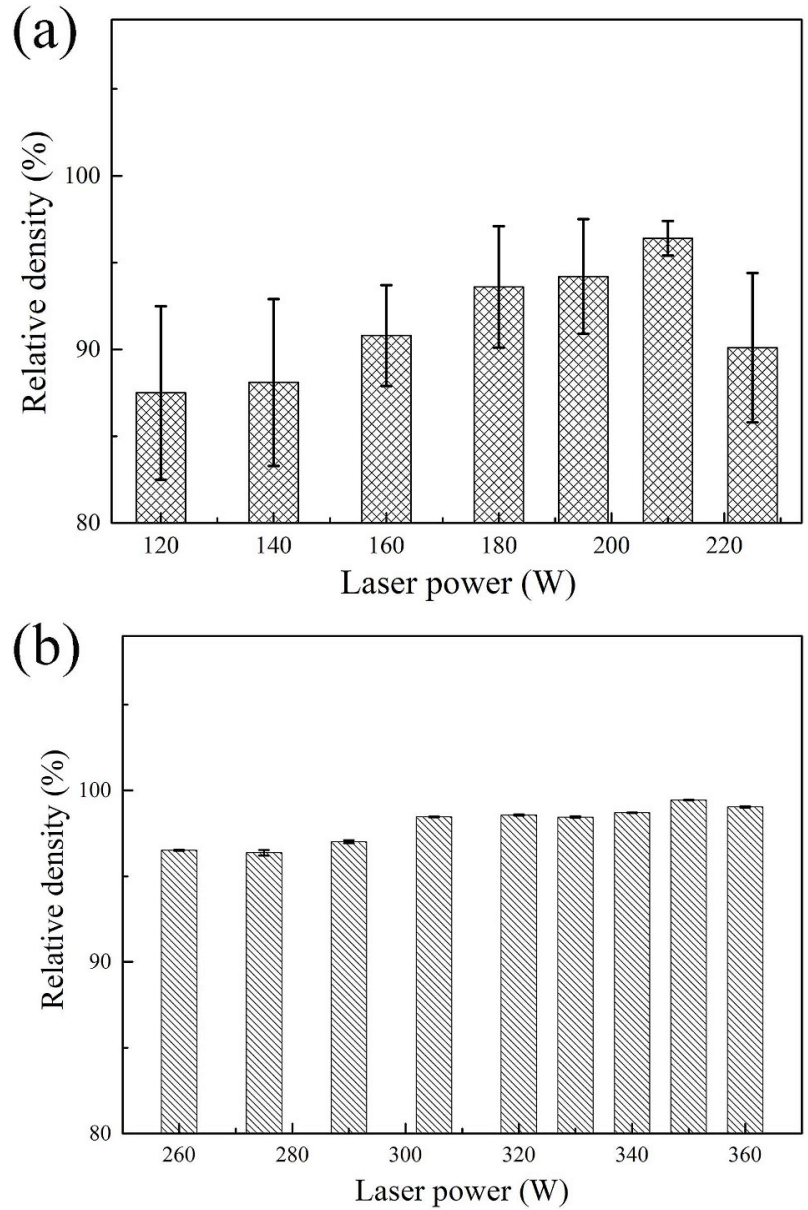

Fig. 2. The relative density of SLM processed (a) Al-18Si and (b) Al-50Si on function of laser powder.

increases as laser powder increases. As reported by our previous works $[2,14]$, fortifying the laser power enlarged the size of molten pool, and then the relative density of SLM processed sample increases. After the input energy is excess, the porosity rapidly increases given to the "keyhole" formation (see in Fig. 2 (a)). On the other hand, the Al-50Si alloy presents a slight decrement in relative density with excess (as shown in Fig. 2 (b)), which can be contributed to the high flowability of metal liquid in high silicon hypereutectic Al-Si alloys [18]. In details, $\mathrm{Al}-18 \mathrm{Si}$ and Al-50Si samples possess highest relative density about of 96.5\% and 99.4\% respectively. According to the work of Aminul Islam et al. [19], the porosity has a great impact on tribological behaviour and material removal during wear. Therefore, in this work, the samples with similar relative density of $96.5 \%$ for both $\mathrm{Al}-18 \mathrm{Si}$ and $\mathrm{Al}-50 \mathrm{Si}$ are chosen for avoiding the influence of porosity on tribological behaviour.

The XRD patterns of SLM processed Al-50Si and Al-18Si alloys are shown in Fig. 3. It can be seen that only $\mathrm{Al}$ and $\mathrm{Si}$ phases can be observed, which indicates the no oxidation and nitridation take place during SLM process. In details, the silicon changes from secondary to main phase, when silicon content increases from $18 \%$ to $50 \%$.

The microstructure (before and after etching) of SLM processed Al18Si and Al-50Si alloys, which are observed by Optical Microscopy, are shown in Fig. 4. The porosity appears in both Al-18Si and Al-50Si samples with relatively uniform distribution. In case of SLM processed Al-18Si alloy, some partial melted particles are observed, which tend to form the crescent pores. Additionally, the size of porosity in Al-18Si sample is smaller than $50 \mu \mathrm{m}$. In contrast, the SLM processed Al-50Si sample presents a mixed structure of porosity, which consisted by few pores with hundreds and major dozens of micrometres. Furthermore, the microstructures at high magnification are shown in Fig. 4 (c and d). 


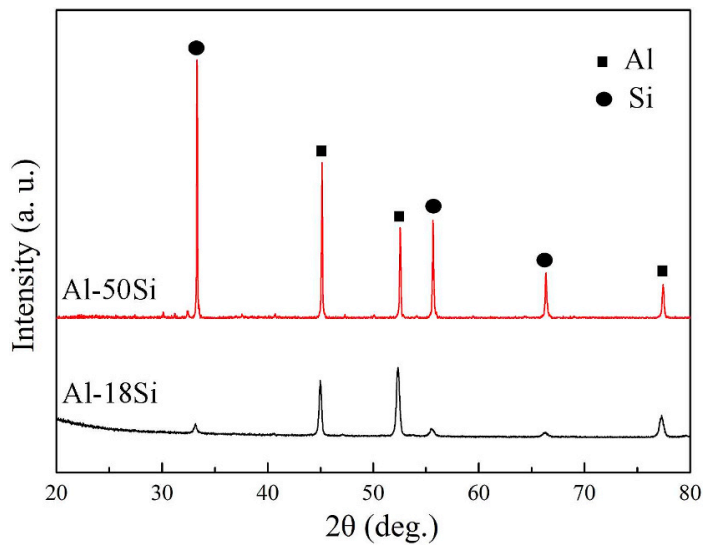

Fig. 3. XRD patterns of SLM processed Al-18Si and Al-50Si alloys with similar relative density.

Different from conventional casted hypereutectic Al-Si alloys [3], the SLM processed sample presents an ultra-fin microstructure. Moreover, the size of primary silicon increases slight, when silicon content increases from $18 \%$ to $50 \%$. As shown in Fig. 4 (d), the average size of primary silicon in SLM processed Al-50Si alloy is about of $3.12 \mu \mathrm{m}$, which is significantly lower than that of conventional casted high silicon-aluminium alloys about of hundreds micrometres [7].

Fig. 5 shows the microstructure of SLM processed Al-18Si and Al50Si, which was observed by Scanning Electron Microscopy, with focus on primary silicon. Both $\mathrm{Al}-18 \mathrm{Si}$ and Al-50Si alloys present a mixed microstructure of particle eutectic (P-eutectic) and fine primary silicon phase. As the silicon content increases, the proportion of primary silicon increases. Additionally, the primary silicon keeps the small dimensions about $2-3 \mu \mathrm{m}$ for both cases. This fine microstructure is attributed to the ultra-high cooling rate during the solidification of SLM process, which causes the different microstructural feature to lowcooling-rate conventional casted sample. For example, as shown in Fig. 5 (a), the particle eutectic structure of Al-18Si sample presents an almost nano-sized microstructure. It's worth nothing that some microcracks appears on the silicon phase of SLM processed Al-50Si, which can be attributed to the low ductility of silicon phase, and the high residual stress of SLM processed sample [20] (see in Fig. 5 (b)).

The coefficient of friction and wear rate of SLM processed Al-18Si and Al-50Si alloys are shown in Fig. 6. In general, both Al-18Si and Al$50 \mathrm{Si}$ alloys present similar friction coefficient about of 0.4 , which are stale after a sliding distance supervisor $10 \mathrm{~m}$. It is worthy to note that the variation tendency of friction coefficient is different at the beginning of sliding. In case of Al-18Si, friction coefficient decreases from 0.7 to 0.4 , as the sliding distance increases to $10 \mathrm{~m}$. To the contrary, the friction coefficient of Al-50Si increases from 0.2 to 0.4, which also possesses higher fluctuation than that of $\mathrm{Al}-18 \mathrm{Si}$. In the point view of wear rate, the Al-18Si presents a slight higher wear resistance than that of Al-50Si sample. In details, the wear rate increases from 7.0 to $8.1 \diamond 10^{-4} \mathrm{~mm}^{3} /(\mathrm{N} \diamond \mathrm{m})$, when silicon content increases from $18 \%$ to $50 \%$. As reported by Deuis et al. [3], the wear rate increases rapidly in case of conventional casted hypereutectic Al-Si alloys, which is different from SLM processed sample in this work. As shown in Figs. 4 and 5 that synthesize the obtained microstructures, this difference can be attributed to the ultra-fine microstructure of SLM processed hypereutectic AlSi alloys. Then, the tribological behaviour of SLM processed hypereutectic Al-Si alloys will be discussed with focus on the distinct microstructural properties in discussion part.

The wear surfaces of SLM processed Al-18Si and Al-50Si alloys at several magnifications, which are observed by SEM, are shown in Fig. 7. On the whole, as shown in Fig. 7 ( $a$ and b), the wear traces for both samples show the similar feature, which consisted by continuously linear grooves. But, instead of debris on wear surface of Al-18Si, some fragments appear on the Al-50Si sample (see in Fig. 7 (b)). Fig. 7 (d) presents that the delamination phenomenon appears between two grooves in case of Al-50Si alloy. As silicon content decreases to $18 \%$, a smooth groove, which is surround by debris, was observed. The high magnification image of this smooth groove (see in Fig. 7 (e)) shows that the micro-cracks and small-sized silicon particle could be observed in grooves. These cracks appear at the Al-matrix with regular distance about of $3 \mu \mathrm{m}$. The silicon particle size in grooves is similar to the silicon in particle-eutectic microstructure. On the other hand, as shown in Fig. 7 (f), Al-50Si sample presents the large-sized silicon and cracks, which appear in the silicon particle with random distribution.
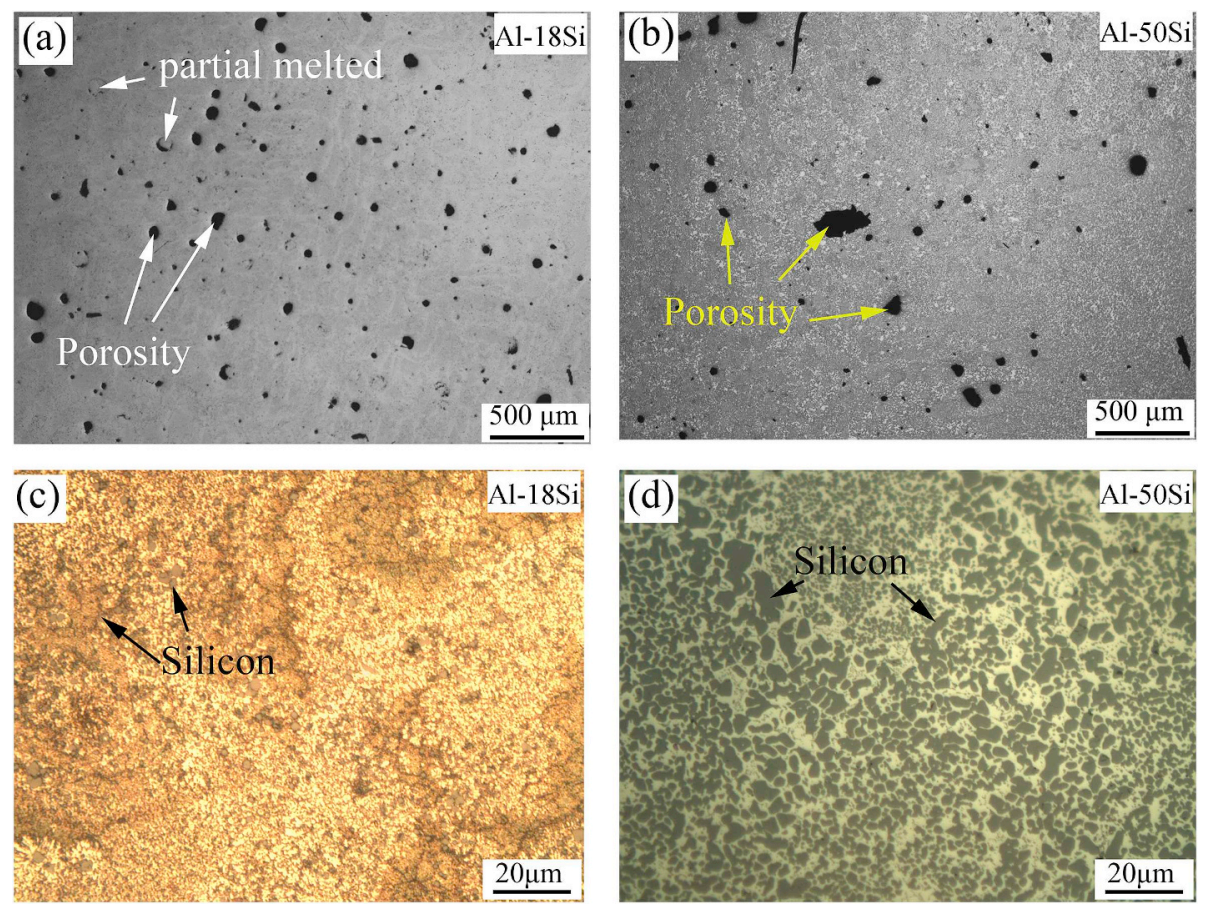

Fig. 4. OM images of SLM processed (a and c) Al-18Si alloy and (b and d) Al-50Si alloy (a and b: before etched; $c$ and d: after etched). 

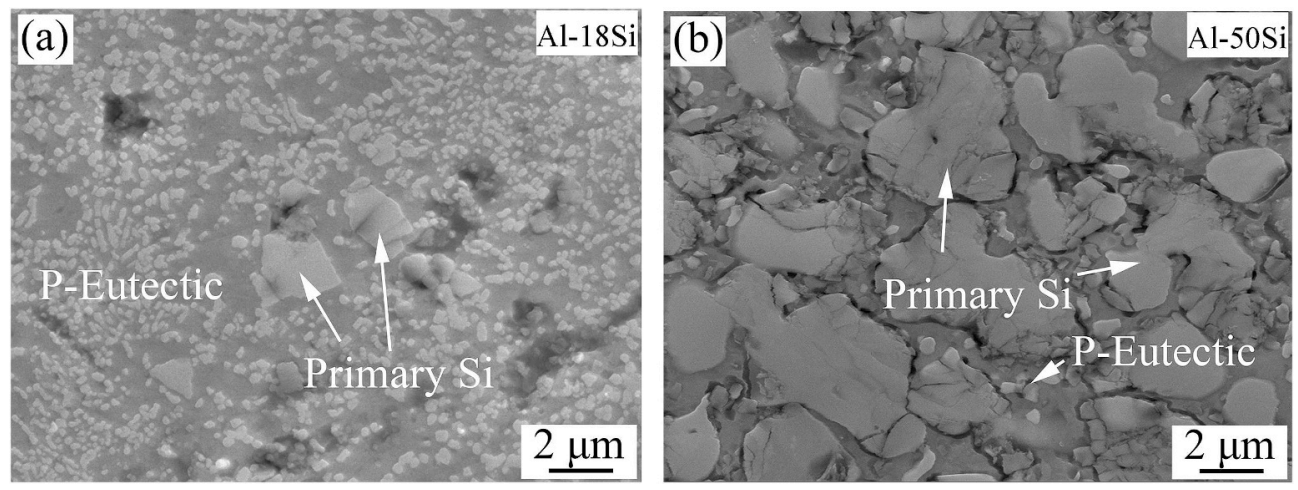

Fig. 5. SEM image of SLM processed (a) Al-18Si and (b) Al-50Si alloys with several porosity (P-eutectic: particle eutectic).

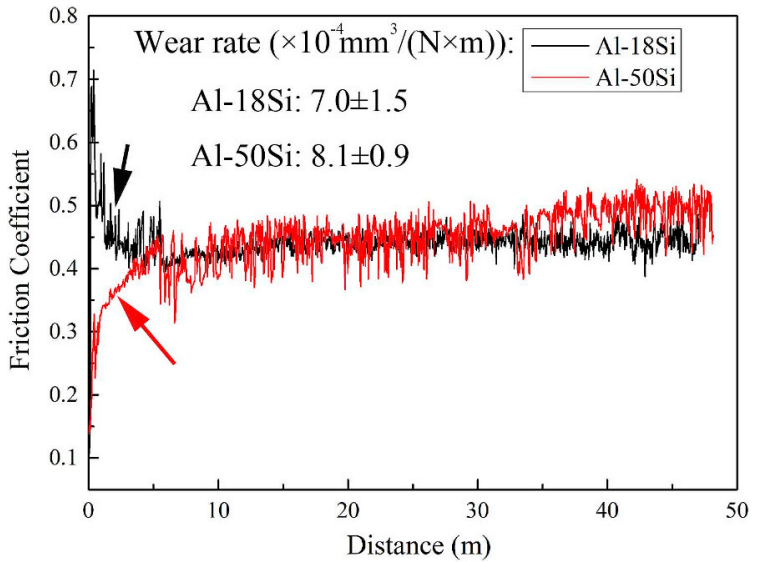

Fig. 6. Friction coefficient and wear rate of SLM processed Al-18Si and Al-50Si alloys.

\section{Discussion}

As mentioned in Figs. 4 and 5, be differ from the microstructure of conventional casted sample, SLM processed hypereutectic Al-Si alloys possess the distinct particle-eutectic microstructure for both $\mathrm{Al}-18 \mathrm{Si}$ and Al-50Si. It can be attributed to high cooling rate during the solidification of SLM process, which is beneficial to the nucleation behaviour of primary silicon. Thus, only small-sized particulate primary silicon and supersaturated $\mathrm{Al}(\mathrm{Si})$ are observed. Additionally, as the silicon content increases, the size of primary silicon increases. Thus, it can be reasonable assume that the SLM processed hypereutectic Al-Si alloys presents a pseudo eutectic structure, which consists by supersaturated $\mathrm{Al}(\mathrm{Si})$ and primary silicon (see in Fig. 8 (b and c)). When silicon content increases, the size of primary silicon increases. Therefore, the tribological behaviour of SLM processed hypereutectic Al-Si alloys with a focus on the pseudo eutectic structures is schematically illustrated in Fig. 8.

For the SLM processed hypereutectic Al-Si with different silicon content, the wear mechanism in this work are based on the third body abrasion, which are mainly consist by fragments of silicon phase and the possible oxides formed during sliding process. However, in detailed difference, according to the sized of silicon phase, three different hypereutectic microstructures are analysed: (a) casted $\mathrm{Al}-\mathrm{Si}$, which is summarised from literature [21,22], (b) SLM processed Al-50Si and (c) SLM processed Al-18Si. On the basis of morphologies of primary silicon, the sliding behaviour was divided into 3 steps. In case of casted hypereutectic Al-Si alloy (see in Fig. 8 (a)), as the load was applied, the large primary silicon particles were crushed into small pieces due to the low ductility of silicon. Then, during the sliding procedure, the large fragments of primary silicon were delaminated and pulled out from $\mathrm{Al}$ matrix [3], which causes a high material removing efficiency and low
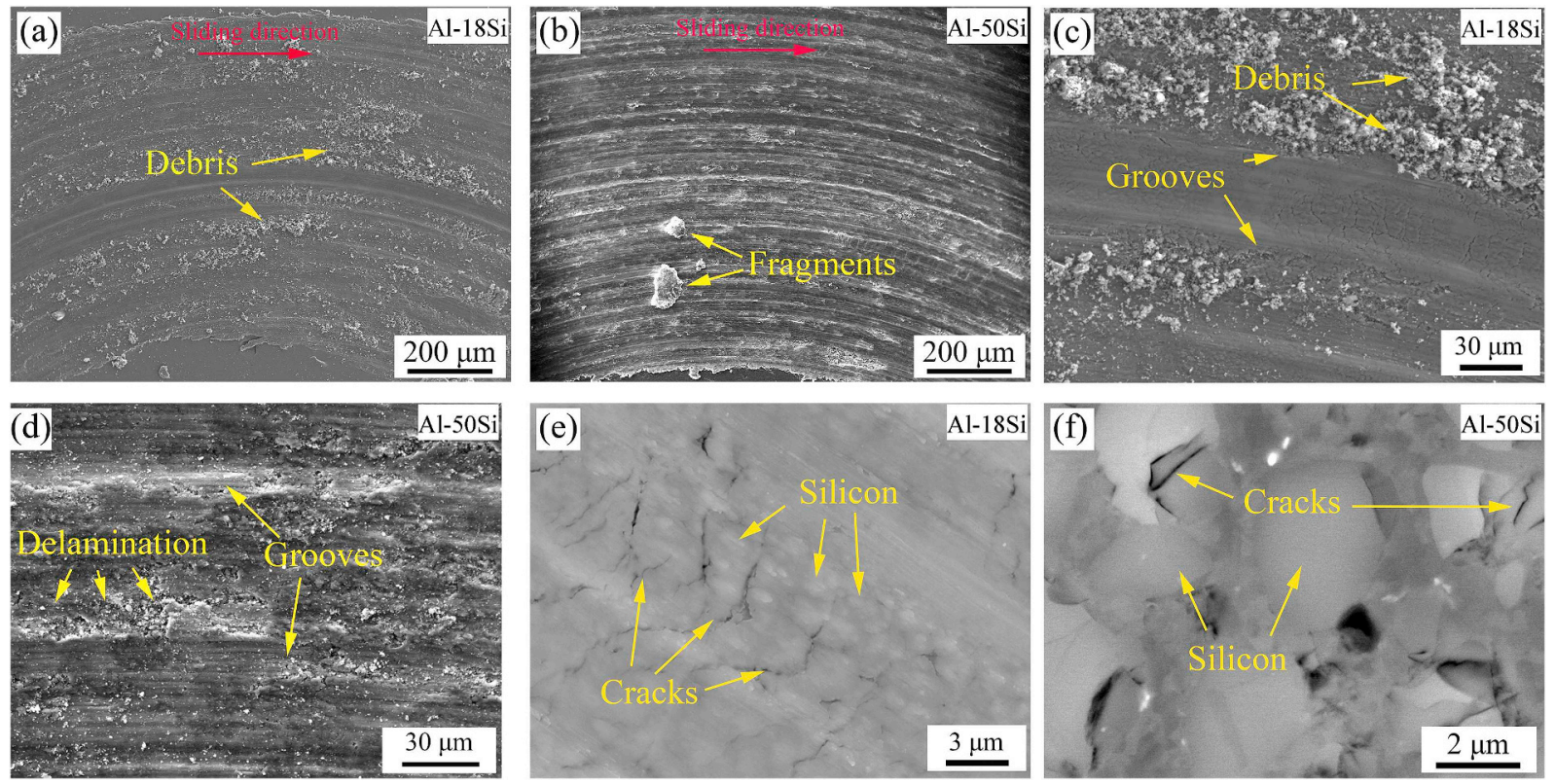

Fig. 7. SEM images of wear surface of SLM processed (a, c and e) Al-18Si and (b, d and f) Al-50Si with almost dense structure. 

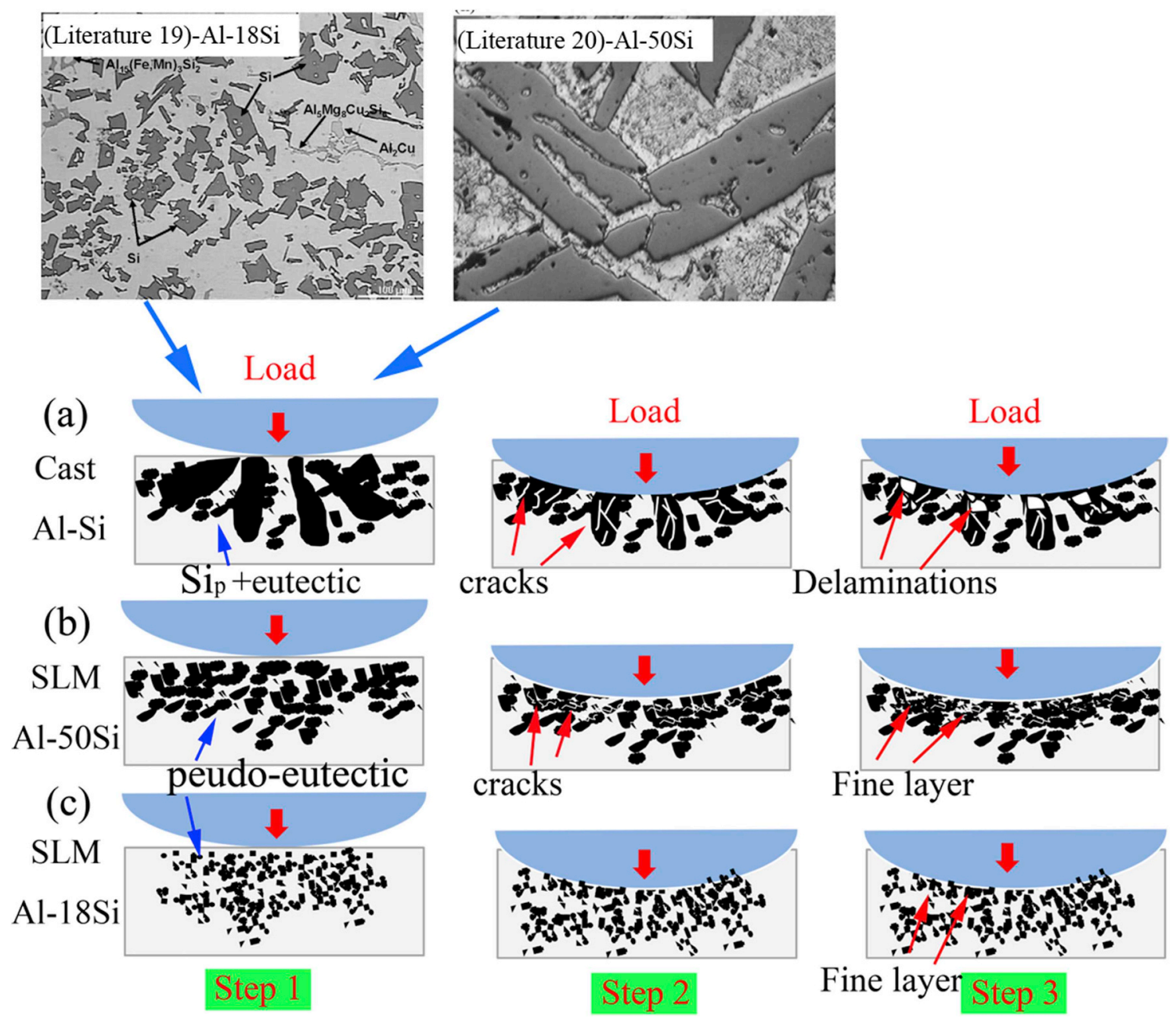

Fig. 8. Schematic illustration of tribological behaviour of (a) casted and SLM processed hypereutectic (b) Al-50Si and (c) Al-18Si samples.

wear resistance. However, in case of SLM processed Al-50Si, no large primary silicon appears in the pseudo eutectic microstructure (Fig. 8 (b)). The micro crack also appears on the low ductility silicon particle with loading process (see in Fig. 7 (f)). These small silicon fragments will be further inlayed into Al matrix and form a layer between counterpart and as-fabricated materials, which consisted by small silicon fragments and Al-Si matrix. In our previous work [2] and as in Ref. [3], the similar results were also reported in case of Al-Si alloys and their composite. With the decrement of silicon content, the ultra-fine silicon particles are not crushed into pieces after loading and during sliding process. Those silicon particles are just inlayed into $\mathrm{Al}$-matrix and then also form a fine interfacial layer. The repeatable "welding-fracture" process generated the debris during the sliding. When the friction appears between counterpart and test specimen, the two are welded together as the result of high temperature and pressure. Then, the further relative displacement between them leads to a fracture behaviour. The repetition of this discontinuous wear process is defined as "weldingfacture" wear mode. On the other hand, the "welding-fracture" tribological behaviour (Al-18Si) shows higher friction coefficient than that of abrasive (Al-50Si), due to the high strength metallurgical bonding between count part and high ductile $\mathrm{Al}$ matrix. Thus, at the beginning of sliding, the friction coefficient of Al-18Si is higher than that of Al50Si. When the stable fine interfacial layer between counterpart and asfabricated material is formed, the friction coefficient tends to be a constant for both the SLM processed hypereutectic Al-Si alloys.

\section{Conclusion}

In this work, the tribological behaviour of SLM processed hypereutectic Al-Si alloys was investigated with focus on the distinct pseudo eutectic microstructure. This pseudo eutectic is consisted by supersaturated $\mathrm{Al}(\mathrm{Si})$ and primary silicon phases. As silicon content increases from $18 \%$ to $50 \%$, the size of primary silicon increases from sub-micro to micrometres with keeping the pseudo eutectic structure. Both the Al$18 \mathrm{Si}$ and $\mathrm{Al}-50 \mathrm{Si}$ alloys show higher wear resistance than that of conventional casted sample [23]. Moreover, as the silicon content increases from $18 \%$ to $50 \%$, the wear rate remains the similar value. Be differ from the tribological behaviour of casted hypereutectic Al-Si alloys, which consisted crushing-delamination-pull out procedure, the SLM processed sample presents a simple (crushing)-inlaying-abrasive due to the fine pseudo-eutectic microstructure.

\section{Acknowledgement}

The work was supported by the National Key R\&D Program of China (Grant No. 2016YFB1100100) and the Fundamental Research Funds for the Central Universities (Grant No. 31020180QD130).

\section{References}

[1] Torabiana H, Pathaka JP, Tiwaria SN. Wear characteristics of Al-Si alloys. Wear 1994:172:49-58.

[2] Kang N, Coddet P, Chen C, Wang Y, Liao H, Coddet C. Microstructure and wear behavior of in-situ hypereutectic Al-high Si alloys produced by selective laser 
melting. Mater Des 2016;99:120-6.

[3] Deuis RL, Subramanian C, Yellup JM. Dry sliding wear of aluminium composites-A review. Compos Sci Technol 1997;57:415-35.

[4] Shankar S, Riddle YW, Makhlouf MM. Nucleation mechanism of the eutectic phases in aluminum-silicon hypoeutectic alloys. Acta Mater 2004;52:4447-60.

[5] Hanna MD, Lu SZ, Hellawell A. Modification in the aluminum silicon system. Metall Mater Trans 1984;15:459-69.

[6] Li Q, Xia T, Lan Y, Zhao W, Fan L, Li P. Effect of rare earth cerium addition on the microstructure and tensile properties of hypereutectic Al-20\%Si alloy. J Alloy Comp 2013;562:25-32.

[7] Gao B, Hu L, Li S-w, Hao Y, Zhang Y-d, Tu G-f, Grosdidier T. Study on the nanostructure formation mechanism of hypereutectic Al-17.5Si alloy induced by high current pulsed electron beam. Appl Surf Sci 2015;346:147-57.

[8] Hogg SC, Lambourne A, Ogilvy A, Grant PS. Microstructural characterisation of spray formed Si-30Al for thermal management applications. Scripta Mater 2006;55:111-4.

[9] Chen Z, Wu X, Tomus D, Davies CHJ. Surface roughness of selective laser melted Ti6Al-4V alloy components. Add Manuf 2018;21:91-103.

[10] Murr LE, Gaytan SM, Ramirez DA, Martinez E, Hernandez J, Amato KN, et al. Metal fabrication by additive manufacturing using laser and electron beam melting technologies. J Mater Sci Technol 2012;28:1-14.

[11] Gu D, Hagedorn Y-C, Meiners W, Meng G, Batista RJS, Wissenbach K, et al. Densification behavior, microstructure evolution, and wear performance of selec tive laser melting processed commercially pure titanium. Acta Mater 2012;60:3849-60.

[12] Kang N, Fu Y, Coddet P, Guelorget B, Liao H, Coddet C. On the microstructure, hardness and wear behavior of Al-Fe-Cr quasicrystal reinforced $\mathrm{Al}$ matrix composite prepared by selective laser melting. Mater Des 2017;132:105-11.

[13] Pauly S, Löber L, Petters R, Stoica M, Scudino S, Kühn U, et al. Processing metallic glasses by selective laser melting. Mater Today 2013;16:37-41.

[14] Kang N, Coddet P, Liao H, Baur T, Coddet C. Wear behavior and microstructure of hypereutectic Al-Si alloys prepared by selective laser melting. Appl Surf Sci 2016;378:142-9.

[15] Attar H, Prashanth KG, Chaubey AK, Calin M, Zhang LC, Scudino S, et al. Comparison of wear properties of commercially pure titanium prepared by selective laser melting and casting processes. Mater Lett 2015;142:38-41.

[16] Bruschi S, Bertolini R, Bordin A, Medea F, Ghiotti A. Influence of the machining parameters and cooling strategies on the wear behavior of wrought and additive manufactured Ti6Al4V for biomedical applications. Tribol Int 2016;102:133-42.

[17] Han Q, Geng Y, Setchi R, Lacan F, Gu D, Evans SL. Macro and nanoscale wear behaviour of $\mathrm{Al}-\mathrm{Al} 2 \mathrm{O} 3$ nanocomposites fabricated by selective laser melting. Composites Part B 2017;127:26-35.

[18] Kang N, Coddet P, Chen C, Wang Y, Liao H, Coddet C. Microstructure and wear behavior of in-situ hypereutectic Al-high Si alloys produced by selective laser melting. Mater Des 2016;99:120-6.

[19] Islam MA, Farhat ZN. Effect of porosity on dry sliding wear of Al-Si alloys. Tribol Int 2011;44:498-504.

[20] Kang N, Coddet P, Ammar M-R, Liao H, Coddet C. Characterization of the microstructure of a selective laser melting processed Al-50Si alloy: effect of heat treatments. Mater Char 2017;130:243-9.

[21] Chen M, Alpas AT. Ultra-mild wear of a hypereutectic Al-18.5wt.\% Si alloy. Wear 2008;265:186-95.

[22] Dai HS, Liu XF. Refinement performance and mechanism of an Al-50Si alloy. Mater Char 2008;59:1559-63.

[23] Gode C, Yilmazer H, Ozdemir I, Todaka Y. Microstructural refinement and wear property of Al-Si-Cu composite subjected to extrusion and high-pressure torsion. Mater Sci Eng, A 2014;618:377-84. 